DOI: 10.15393/j9.art.2012.360

Оксана Геннадьевна Абрамова

кандидат филологических наук, доиент кафедры скандинавской филологии филологического факультета, Петрозаводский государственный университет

(Петрозаводск, Российская Федераиия)

poetica@post.com

\title{
БОГОБОРЧЕСКИЕ МОТИВЫ В ПОЭМЕ В. МАЯКОВСКОГО «ОБЛАКО В ШТАНАХ»
}

Аннотация: Статья посвящена теме богоборчества в творчестве В. В. Маяковского. Основное внимание в работе уделено анализу поэмы «Облако в штанах». Первоначальное заглавие поэмы - «Тринадцатый апостол» - можно назвать квинтэссенцией ее содержания. Такое название свидетельствует о богоборческом начале и протесте поэта против церковных догм. В статье рассматривается комплекс богоборческих мотивов в художественной структуре поэмы «Облако в штанах", а также способы их футуристической трансформации. В зооморфном образе Вселенной, появившемся в завершении поэмы, нет ни Бога, ни Человека. Конфликт с миром, забывшим Бога, доводит лирического героя до «сумасшествия» богоборчества, бесконечно возвращая его на Голгофу, в толпу, которая выбирает Варавву. В этом заключается глубочайший трагизм поэмы.

Ключевые слова: Библия, богоборчество, мотив, Маяковский, «Облако в штанах»

Б огоборчество, находящееся в сложных отношениях сопротивопоставления с религиозной и атеистической идеями, - одна из мировоззренческих установок «человека модерна» (термин Н. Ю. Грякаловой) [2]. Не раз поэтически открыто декларированное В. Маяковским богоборчество рассматривалось исследователями с разных позиций: во-первых, в более узком (социальном) понимании - как часть темы бунта против «старого мира» (вслед поэту неизменно выделяемой критиками разного времени и разных идеологических установок); во-вторых, как часть комплексного тематического ряда, включенного в проблему эстетических и религиозно-философских воззрений художника; в-третьих, богоборчество Маяковского неразрывно связано с проблемой религиозности русского авангарда.

В статье о футуризме «Владимир Маяковский (“Мистерия” или “Буфф”)» Иванов-Разумник пишет о том, что «смысл и сущность всей деятельности подлинного футуризма» заключается в том, чтобы «повторить о себе слова Заратустры: “я - верхом на вещи”». На этом выстраивается модель «богоборчества» футуризма и конкретно Маяковского. Слово богоборчество в статье закавычено, этим автор указывает на то, что по существу борьба идет не с Богом как 
таковым, а с неким «царем мира», «всесветным Мещанином», «Повелителем Всего», у которого сам Бог «на побегушках». Маяковский видит перед собой «своего Бога»:

Для него, «воспевающего машину и Англию, весь мир - машина, для него, проводящего жизнь между телефонной трубкой и штепселем электрической лампы, весь мир - «вещь». Ибо он - «тринадцатый апостол» нового евангелия: благовестил «вещи». Апостол, раб и богоборец против этого своего Бога (курсив наш - O. А.) — все сразу $[4,707]$.

Приводя для сравнения героев Достоевского, Иванов-Разумник характеризует «богоборчество» Маяковского как «наивнейшее, мелкое, детское»:

...после глубин Кириллова и Ивана Карамазова - бледно и бедно звучат все эти вопли и проклятия криком кричащего футуриста; сильные внешне, слабы и нищи они внутренне $[4,710]$.

В интерпретации автора статьи поэт не смог дойти до Бога, «подобно мелкому бесу - мелкий бог стал на его пути»: это трагический путь, завершающийся провалом.

Н. Устрялов в статье 1920 г. «Религия революции (Владимир Маяковский)» также поднимает вопрос о власти вещи и проводит параллели с Достоевским, однако выстраивает иную модель. Он утверждает, что, «как и Ницше, Маяковский - религиозная натура, убившая Бога» [12, 502], не знающая покоя, чем и отличается от «равнодушного атеиста». На место Бога Маяковский ставит человека, тем самым вписываясь, по определению Устрялова, в «седую, длинную» традицию люциферианства:

...от соблазна змея и Вавилонской башни до Штирнера (homo как deus), Фейербаха, Ницше. «Человекобожество» Достоевского... Но только все это вдруг облеклось в плоть и кровь, разлилось вширь бесконечную, стало потрясающим фактом, в масштабе всемирно историческом. Вот почему и голос нового поэта звучит неслыханным полнозвучием, подобно грохоту камней, низвергаемых титанами $[12,505]$.

Но «земные небеса», при провозглашении которых Человек оказался наверху, а Бог - внизу, перечеркивает одно: «вне живого Бога праздник вещей невозможен» $[12,508]$. Согласно Устрялову, «опрокинутая иерархия ценностей мстит за себя»; оказывается, в корону Творца не так-то просто облачиться, отчего мучается «обезбоженная, но до конца религиозная душа» поэта.

Еще один подход к теме богоборчества Маяковского предложил В. Силлов в статье «Революция духа (Ницше и Маяковский)» в 1921 г.: Ницше указал человечеству путь, сам на него не вступая, а «Маяковский - исполнение проповеди Ницше» [9, 603]. Далее Силлов пишет:

Маяковский - второй и, может быть, самый сильный, после Ницше удар по идолам старого мира $[9,606]$. 
Однако если Иванов-Разумник говорит о том, что поэт (Маяковский) «не дошел» до Бога, Устрялов утверждает, что Маяковский, как и Ницше, «убил» Бога, то Силлов считает, что «Маяковский не убивает Бога, а очеловечивает его». Это очеловечивание, восходящее к эллинскому пониманию божества, «дает Маяковскому возможность выступить против Бога» $[9,606]$.

О близости богоборчества Маяковского «вчерашнему дню русской литературы» в 1930 г. писал Р. Якобсон:

Сны Маяковского о будущем, вторящие версиловской утопии, его гимн человекобожеству, богоборчество «тринадцатого апостола», его этическое неприятие Бога, - все это куда ближе вчерашнему дню русской литературы, чем дежурному официальному безбожию [16].

Советские критики вписывали богоборческие тенденции творчества Маяковского в пафос советского жизнеустройства, заостряя внимание на социально-историческом аспекте его бунта: борьба ведется с «ненавистным миром капитализма», постановка вопроса о религиозных воззрениях Маяковского не имеет под собой почвы. В Большой советской энциклопедии 1938 г. о поэмах «Облако в штанах» и «Флейта позвоночник» Е. Тагер писал:

Личный и интимный сюжет приобретает социальное осмысление, любовная драма развертывается как трагический конфликт между большим, подлинно человеческим чувством и тупым, лживым моральным кодексом буржуазного общества. Отсюда - мотивы гнева и бунта, социально заостренного протеста, которыми разрешается любовный сюжет произведения [10, стб. 548].

Бунтарство раннего лирического героя Маяковского автор статьи называет индивидуалистическим, лишенным перспектив, отчего «страстное отрицание капитализма перемежалось настроениями глубокого пессимизма, тоски и одиночества, мятежная активность подчас уступала мотивам жертвенности, готовности собственным страданием искупить страдания человечества, все мироощущение поэта окрашивалось порой в тона трагического надрыва» [10, стб. 549]. Согласно Тагеру, трагическое мироощущение поэта складывается от внутреннего «несовершенства», слабости, которые Маяковский преодолеет в послеоктябрьский период:

Анархизм индивидуалистического бунтарства скоро сменился сознательной и целеустремленной революционной направленностью. Трагический надрыв дореволюционной поры уступил место оптимистическому пафосу борьбы и победы [10, стб. 549].

В постсоветский период религиозная и богоборческая темы возвращены в проблемно-тематическое поле творчества Маяковского. В 1993 г. Вышла статья М. Пьяных «Богоборец с сердцем Христа» [8], в которой жизнь Маяковского рассмотрена как «действо» ${ }^{2}$. Главный герой этого «действа» - поэт Владимир Маяковский. Такой 
подход соответствует авангардистской модели проецирования художника на творчество, «снятия границ между лирическим и эмпирическим». Как пишет Е. Тырышкина, «авангардисты стремятся к постоянному перешагиванию от реальности условной к реальности данной, и поэт постоянно колеблется в своем образе от фигуры живущей к фигуре сконструированной» $[11,176]$.

«В первых двух актах действа», как выражается Пьяных, имея в виду, по всей видимости, раннее творчество Маяковского, поэт «стремится поставить своего лирико-трагедийного героя, выражающего устремления всего человечества, на место Бога - одряхлевшего, беспомощного, не способного на какие-либо деяния ради людей» $[8,46]$. Возникает идея богозамещения. Не отрицая влияния Ницше на образный ряд и идейное содержание текстов Маяковского, Пьяных проводит ранее уже отмеченную параллель с героями Достоевского, в творчестве последнего находит художественную матрицу лирического героя Маяковского:

Можно с уверенностью сказать, что богоборец с сердцем Христа ведет свою родословную не от Заратустры, а от Достоевского [8, 48].

Т. Жирмунская, развивая идеи Якобсона, полагает, что богоборчество Маяковского - не атеизм, мироощущение поэта имеет христианские основы. Маяковский «страдал от катастрофического несовершенства быта и бытия», что прочитывается в его поэзии, и даже в «новом» мире, в который он искренне верил, как оказалось, гармонии не было:

...не было ни вокруг, ни в нем самом ни чистоты, ни милости, ни миротворчества. Не было Любви. А жгучая, гиперболизированная тоска по ним была [3].

Важный пласт художественного универсума Маяковского - библейская символика: образы, мотивы, цитаты и реминисценции Священного Писания - стал предметом отдельного исследования, проведенного Д. Ю. Шалковым. Обратившись к творчеству поэта 1912-1918 гг., Шалков детально рассмотрел особенности функционирования «Книги книг» в произведениях Маяковского, в том числе в поэме «Облако в штанах» [14]. Основные результаты этого исследования были представ лены в статье “Обыкновенное евангелие” “тринадцатого апостола”: библейская символика в поэме В. В. Маяковского “Облако в штанах”». Автор приходит к выводу:

...Мотивы и образы Священного Писания пронизывают всю поэму «Облако в штанах» и формируют внушительное эмоционально-смысловое поле. Это мотивы искупительной жертвы, распятия, мученичества, непонятого и осмеянного пророка, «вавилонский» мотив, мотив декапитации (обезглавливания) и ряд других. Ведущую роль здесь играют образы и ситуации, восходящие к Новому Завету, в особенности - христологическая символика, которая образует постоянный реминисцентный фон произведения $[15,31]$. 
Комментариев и наблюдений по проблемам религиозности и богоборчества в творчестве Маяковского немало. В их освещении, как прави ло, поэма «Облако в штанах» занимает одну из самых важных позиций, наравне с трагедией «Владимир Маяковский» (1913) и поэмой «Человек» (1916-1917). Обратившись к поэме «Облако в штанах», мы постарались проследить, как богоборческие мотивы включены в сюжет и проблематику произведения.

Первоначальное заглавие поэмы, характеризующее лирического героя, «Тринадцатый апостол» можно назвать квинтэссенцией содержания. Такое название, как считают многие исследователи, свидетельствует о богоборческом начале и протесте поэта против церковных догм. В нем концентрированно выражены притязания Маяковского на то, чтобы вписать себя в апостолы новой веры.

С другой стороны, Л. Ф. Кацис, обращаясь к начальному образу-заглавию, указывает на его нарративную связь с именем Иоанна Златоуста («Я, / златоустейший, / чье каждое слово / душу новородит...» $\left.{ }^{3}\right)$, вносящим новые коннотации в метафорический сюжет «тринадцатого апостола»:

Апостолов, как известно, было всего двенадцать. Тринадцатым иногда называли Иоанна Златоуста... это была метафора, оценивающая значение сочинений Иоанна Хризостома. Он лишь метафорически соотносился с евангельскими апостолами $[6,86]$.

В образе «тринадцатого апостола» можно обнаружить связь с апостолом Павлом, о котором К. Кантор пишет:

Он лучше двенадцати понимал учение Иисуса, больше других сделал для распространения Его учения, но и более двенадцати отступал от многих заповедей Учителя... Сам Иисус полагал, что со временем, пусть весьма отдаленным, появятся новые Его апостолы, которые приведут Его учение в согласие с новыми обстоятельствами времени и места. Таким новым апостолом... стал Владимир Маяковский $[5,11]$.

Заглавие «Тринадцатый апостол», хоть и уходит в подтекст, но остается значимым. Не случайно К. Кантор называет свою книгу о Маяковском «Тринадцатый апостол», усматривая «миссию» поэта-футуриста в том, «чтобы провести линию преемственности от Христа к Марксу через Ренессанс» $[5,10]$.

Богоборческие мотивы разворачиваются в сюжете поэмы по принципу концентрических кругов, центром которых является лирический герой, объявивший войну несовершенству мира. Во вступлении конфликтное поле задано оппозицией Человек - человек, где первого, человека с большой буквы, апостольского масштаба, персонифицирует лирический герой, поэт, главный атрибут которого - «окровавленный сердца лоскут». Сердечность и жертвенность являются важными характеристиками Человека, готового 
ценой сердечной жертвы пробудить людей к истинной жизни. Его оппоненты атрибутируются мыслью, которая, «как выжиревший лакей на засаленной кушетке», почивает на «размягченном мозгу» ${ }^{4}$. Таких, по Маяковскому, толпы, легионы, в услужении у них находится «мысль лакей», а «господином» является желудок ${ }^{5}$.

Богоборческие мотивы начинают явно формулироваться лишь во второй части поэмы, где появляется образ «ветхозаветного» карающего бога:

Городов вавилонские башни, возгордясь, возносим снова, а бог города на пашни рушит, мешая слово 6 .

В свободной форме, но с сохранением смыслов, Маяковский воспроизводит сюжет Ветхого Завета, в котором люди, возжелавшие устроить небо на земле, были наказаны за свою гордыню. Конфликт между людьми и Богом усугубляется сотворенным человеком социальным религиозным институтом - церковью, веками давящей «папертью» «на горло».

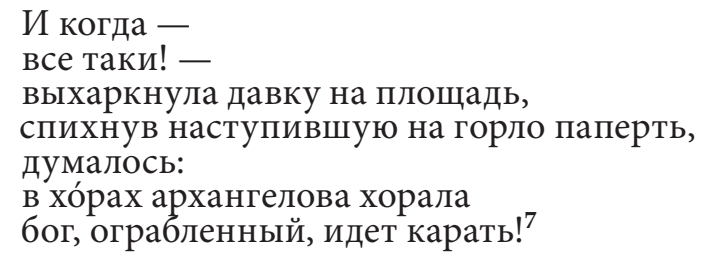

Как пишет М. Вайскопф, «революция в “Облаке” начинается с нового Логоса, воскрешающего “безъязыкую улицу”, - с футуристического словотворчества и живой поэзии, идущей на смену книгам и молитвам» $[1,403]$. Увидев «уличные тыщи», бегущие за поэтом в надежде получить слово спасения, лирический герой берет на себя проповедь «златоустейшего»:

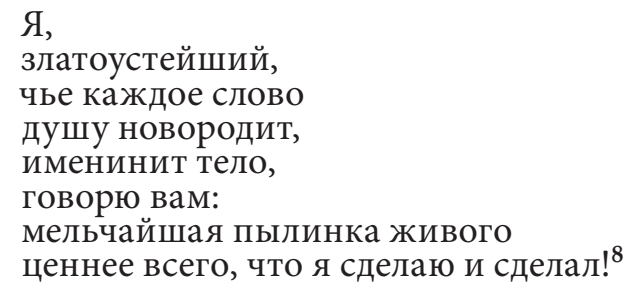

Самоопределение лирического героя «златоустейший», казалось бы, сближает его с образом Иоанна Златоуста, проповедовавшего Христа, однако вектор его «славословия» тут же отклоняется в ницшеанство: 


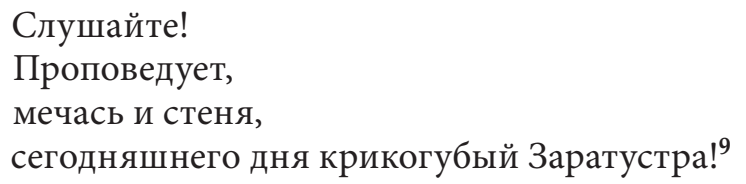

Но и в ницшеанскую концепцию лирический герой не вписывается. Его заявление о том, что «мельчайшая пылинка живого ценнее всего», не соответствует идеям Заратустры Ницше о главенстве сверхчеловека над всем и вся. Определив себя «сегодняшнего дня крикогубым Заратустрой», лирический герой все же идет вслед за Христом:

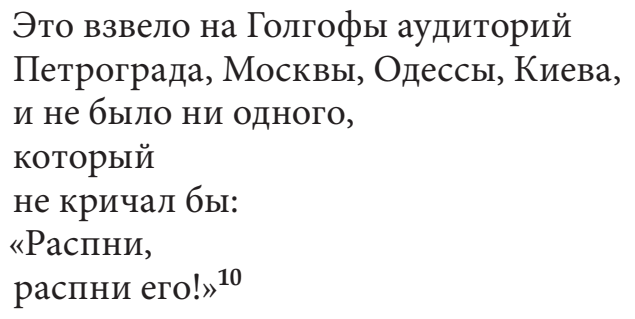

Маяковский прибегает к прямой цитации из Евангелия от Луки: «Но они кричали: распни, распни Его!» (Лк. 23:21). Жертвенность, всепрощение, мученичество, любовь-сострадание становятся в этом эпизоде главными характеристиками героя поэмы:

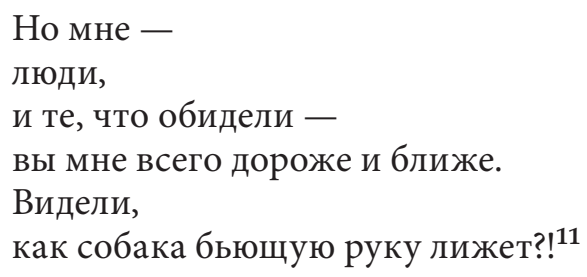

Мотив Голгофы актуализирует в памяти и по-новому представляет вводный мотив «окровавленного сердца» поэта. В новом контексте героическую модель жизни борьбы, которую демонстрирует и проповедует лирический герой, сменяет идея христианского подвижничества. Однако далее новозаветный мотив любви к ближнему удваивается ницшеанским мотивом любви к дальнему:

Я,

обсмеянный у сегодняшнего племени, как длинный

скабрезный анекдот, вижу идущего через горы времени, которого не видит никто ${ }^{12}$. 
Таким образом, двусмысленность первоначального заглавия поэмы закрепляется сюжетно: лирический герой то идет стезей Христа, то следует путем Заратустры. Постоянно меняющийся вектор движения сопровождают мотивные оппозиции: страдания праздника, жертвы во имя людей - радости во имя свое, которые в третьей части поэмы получают новые коннотации. Неприятие одиночества, страдания и смерти, жажда праздника жизни здесь и сейчас задают новое, «карнавальное», шествие героя. Называя себя «площадным сутенером» и «карточным шулером», он провозглашает радость праздника и плоти:

Невероятно себя нарядив, пойду по земле, чтоб нравился и жегся, а впереди на цепочке Наполеона поведу, как мопса. Вся земля поляжет женщиной, заерзает мясами, хотя отдаться; вещи оживут губы вещины засюсюкают: «цаца, цаца, цаца!» 13

Но «праздник» прерывается вмешательством неба. М. Вайскопф на зывает этот эпизод «небесной, солярной контрреволюцией»:

Гром из-за тучи, зверея, вылез, громадные ноздри задорно высморкал, и небье лицо секунду кривилось суровой гримасой железного Бисмарка. $<$...>

Вы думаете это солнце нежненько треплет по щечке кафе? Это опять расстрелять мятежников грядет генерал Галифе! ${ }^{14}$

Образ неба врага у Маяковского низведен на землю и включен в социальную бойню Первой мировой войны. Апофеозом «солярной контрреволюции» становится расправа над землей, «обжиревшей, как любовница, которую вылюбил Ротшильд» ${ }^{15}$. При этом вышеозначенный образ земной цивилизации дискредитирует тот дионисийский праздник свободы духа и плоти, которого ищет «крикогубый Заратустра». С приходом ночи борьба неба и земли затихает, и в душу лирического героя закрадывается сомнение, которое в полном объеме раскроется в последних строках поэмы:

Уже сумасшествие.

Ничего не будет.

Ночь придет, перекусит

и съест ${ }^{16}$. 
В ночном затишье лирическому герою видится богоматерь, при описании которой используется стилистически сниженная лексика - «глазами в сердце въелась богоматерь», «по шаблону намалеванному» ${ }^{17}$. М. Вайскопф усматривает в этом связь поэзии Маяковского с народными религиозными представлениями Средневековья:

Народная, стихийная культура Средневековья... не только славословила господа, но и, предваряя Маяковского, нередко унижала Всевышнего, оплевывая Его в самом прямом смысле слова [1,344].

Одновременно с введением в образную структуру поэмы богоматери возвращается христологическая образность и новозаветный сюжет Голгофы:

$$
\begin{aligned}
& \text { Видишь - опять } \\
& \text { голгофнику оплеванному } \\
& \text { предпочитают Варавву? }
\end{aligned}
$$

Поиски спасения вновь приводят героя на Голгофу, однако новозаветный сюжет предстает здесь трагически усеченным и искаженным, лишенным перспективы Воскресения. Иисус Христос - Имя и Путь Спасения - переименован в «голгофника оплеванного» и замещен лирическим героем, воспевающим гордый мир без Бога, «машину и Англию»:

$$
\begin{aligned}
& \text { Я, воспевающий машину и Англию, } \\
& \text { может быть, просто, } \\
& \text { в самом обыкновенном евангелии } \\
& \text { тринадцатый апостол }{ }^{19} \text {. }
\end{aligned}
$$

Катализатором финального круга богоборческих мотивов в четвертой части поэмы, как и в ее начале, служит «жирный» мир, отвергающий поэта и «укравший» у него возлюбленную: «Как в зажиревшее ухо втиснуть им тихое слово?» ${ }^{20}$ Люди отвернулись от Бога, их идол - потребительство, жиром удушающее и мысль, и сердце, и слух человеческие. Парадоксально, но именно этот безбожный мир, с которым герой не может примириться, толкает его на борьбу с Богом.

Не находя себе товарища среди людей, лирический герой «вылезает» из ада своих переживаний и становится «бок о бок» с «очеловеченным» Богом-стариком («раздобревшие глаза», «седая бровь»). Но это действие, кажущееся попыткой установить теургическое «сотоварищество», оборачивается ярким проявлением богоборческих амбиций. Лирический герой пытается совратить Бога ницшеанским праздником («карусель, вина, танцы, красивейшие девочки»), развенчать («Я думал - ты всесильный божище, / а ты недоучка, крохотный божик» $\left.{ }^{21}\right)$ и в конце концов - убить. Он не 
вступает в диалог с Богом, но пытается «спихнуть» Его, заместить собою. В финале герой предстает падшим ангелом («Я тоже ангел, я был им...» ${ }^{22}$ ), угрожающим Богу и его окружению бандитской расправой:

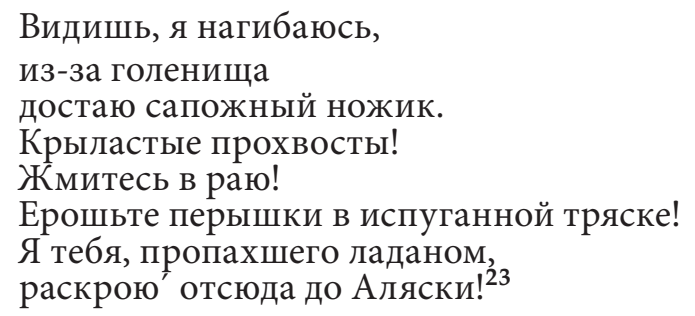

Казалось бы, лирический герой сводит счеты с земным, церковным, образом Бога, что подкрепляется определением «пропахший ладаном» и топонимом Аляска, к тому же угроза убийства Бога экстраполируется в будущее и задана не уверенностью в правоте новой веры, а мукой сомнения:

Вру $я$,

в праве ли,

но я не могу быть спокойней ${ }^{24}$

Однако поэтическое слово у футуриста Маяковского наделено энергией сакрального действия. Небо после угрозы расправы над Богом остается недостижимым, а лирический герой возвращается к тому, с чего начал. Как последний крик протеста и боли неосуществленного «тринадцатым апостолом» божественного космоса человечности и любви в итоговом обращении к небу вновь прорывается желание соперничать теперь уже с сокровенным Богом:

Эй, вы!

Небо!

Снимите шляпу! Я иду! 25

Однако этот крик останется без ответа.

Глухо.

Вселенная спит, положив на лапу

с клещами звезд огромное ухо 26 .

В завершении появляется зооморфный образ Вселенной, в которой нет ни Бога, ни Человека. Новое слово спасения не произнесено, конфликт с миром, забывшим Бога, доводит лирического героя до «сумасшествия» богоборчества, бесконечно возвращая его на Голгофу, в толпу, которая выбирает Варавву. В этом заключается глубочайший трагизм поэмы. 
Богоборчество авангардистов, как пишет Н. В. Крылова, «на поверку оказывается ничем иным, как формой бытования религиозного сознания: борьба с Богом “предполагает признание его живым”» $[7,59]$. В свою очередь богоборческое признание существования Бога «только усложняет положение человека в мире» $[13,107]$, превращает драму человеческого существования в трагедию.

\section{Примечания}

1 Работа выполняется при финансовой поддержке Программы стратегического развития ПетрГУ на 2012-2016 гг. в рамках реализации комплекса мероприятий по развитию научно-исследовательской деятельности.

Слово «действо» Пьяных использует в значении «синтетической драмы, которая включает в себя приметы разных драматургических жанров... подчиненных основному свойству всемирно-исторического действа Маяковского - трагедийному характеру его главного героя и трагедийной структуре его сюжета и композиции» $[8,45]$.

3 Маяковский В. В. Полн. собр. соч.: В 13 т. М., 1955-1961. Т. 1. С. 183.

4 Там же. С. 175.

5 Более детально эта гротескная модель человека и человечества, выраженная в образе «желудка в панаме», развернута в стихотворении В. Маяковского «Гимн обеду».

6 Маяковский В. В. Указ. соч. С. 182.

7 Там же.

8 Там же. С. $183-184$.

9 Там же. С. 184.

8 Там же. С. $183-184$.

10 Там же.

11 Там же. С. 185.

12 Там же. С. 185.

13 Там же. С. 187.

14 Там же. С. 188.

15 Там же. С. 189.

16 Там же.

17 Там же. С. 189.

18 Там же. С. 190.

19 Там же. С. 190.

20 Там же. С. 192.

21 Там же. С. 195.

22 Там же.

23 Там же. С. 195-196.

24 Там же. С. 196.

25 Там же.

26 Там же. 


\section{Список литературы}

1. Вайскопф М. Во весь голос: религия Маяковского // Вайскопф М. Птица тройка и колесница души: Работы 1978-2003 годов. М.: Новое литературное обозрение, 2003. С. 343-486.

2. Грякалова Н. Ю. Человек модерна. Биография - рефлексия - письмо. СПб.: Дмитрий Буланин, 2008. 408 с.

3. Жирмунская T. «За всех расплачусь, за всех расплачусь...» // Континент. 2005. № 124 [Электронный ресурс]. Режим доступа: http:// magazines.russ.ru/continent/2005/124/zh21.html (дата обращения: 16.11.2011).

4. Иванов-Разумник Р. В. Владимир Маяковский («Мистерия» или «Буфф») // В. В. Маяковский: Pro et contra / Сост., вступ. ст., коммент. В. Н. Дядичева. СПб.: РХГА, 2006. С. 692-728.

5. Кантор К. Тринадцатый апостол. М.: Прогресс-Традиция, 2008. 368 с.

6. Кацис Л. Ф. Владимир Маяковский: Поэт в интеллектуальном контексте эпохи. 2-е изд., доп. М.: РГГУ, 2004. 829 с.

7. Крылова Н. В. Медный век: Очерк теории и литературной практики Русского авангарда: Учеб. пособие / Петрозаводск: Изд-во КГПУ, 2002. $128 \mathrm{c}$.

8. Пьяных М. Богоборец с сердцем Христа // Свободная мысль. 1993. № 5. C. $44-50$.

9. Силлов В. Революция духа (Ницше и Маяковский) // В. В. Маяковский: Pro et contra / Сост., вступ. ст., коммент. В. Н. Дядичева. СПб.: РХГА, 2006. С. 603-606.

10. Тагер Е. Маяковский В. В. // Большая советская энциклопедия / Гл. ред. О. Ю. Шмидт. М.: Сов. энциклопедия, 1938. Т. 38. Стб. 547555.

11. Тырышкина Е. Концепция праздника в ранней лирике В. Маяковского // Alexander Graf (Hg.). Festkultur in der russischen Literatur (18. bis 21. Jahrhundert) - Культура праздника в русской литературе XVIII-XXI вв. München, 2010. C. 173-182.

12. Устрялов Н. Религия революции (Владимир Маяковский) // В. В. Маяковский: Pro et contra / Сост., вступ. ст., коммент. В. Н. Дядичева. СПб.: РХГА, 2006. С. 499-512.

13. Фатенков А. Н. Субъект в онтологическом столкновении с Богом // Человек. 2011. № 1. С. 107-123.

14. Шалков Д. Ю. Библейские мотивы и образы в творчестве В. В. Маяковского 1912-1918 годов: Дис. ... канд. филол. наук. Ставрополь, 2008. $230 \mathrm{c}$.

15. Шалков Д. Ю. «Обыкновенное евангелие» «тринадцатого апостола»: библейская символика в поэме В. В. Маяковского «Облако в штанах» // Русская словесность. 2008. № 4. С. 30-37.

16. Якобсон Р. О поколении, растратившем своих поэтов [Электронный peсурс]. Режим доступа: http://avantgarde.narod.ru/beitraege/ff/rja_o_ pokolenii.htm (дата обращения: 13.10.2011). 
Oksana Gennad'evna Abramova

Ph.D. in Philology,
Associate Professor of the Department of Scandinavian Philology,
Faculty of Philology,
Petrozavodsk State University
(Petrozavodsk, Russian Federation)
oksana.abramova@yahoo.com

MOTIFS OF STRUGGLING WITH GOD IN V. MAYAKOVSKY'S POEM «A CLOUD IN TROUSERS»*

\begin{abstract}
The article examines the problem of struggling with God in the works of Vladimir Mayakovsky, with a special focus on his poem A Cloud in Trousers. The poem's original title - The Thirteenth Apostle - presents the quintessence of its content and witnesses the rise of the struggle with God and the poet's protest against the Church dogma. Our article looks at a number of theomachic motifs in A Cloud in Trousers, as well as the means of their transformation in the futuruist world, A zoomorphic image of the Universe which appears at the ending of the poem lacks both God and Man. The conflict with the world that had forgotten its God drives the lyrical protagonist into the 'madness' of struggle against God. This conflict keeps bringing him back to Golgotha, surrounded by the crowd who chooses to let Barabbas go. This is the highest tragedy of Mayakovsky's poem.
\end{abstract}

Keywords: Bible, struggle with God, motif, Mayakovsky, A Cloud in Trousers

\title{
References
}

1. Vaiskopf M. Vo ves golos: religiya Mayakovskogo [At the Top of my Voice: the Religion of Vladimir Mayakovsky]. Vaiskopf M. Ptitsa troika i kolesnitsa dushi: Raboty 1978-2003 godov [Vaiskopf M. Bird Trio and the Chariot of the Soul: the Works of the 1978-2003s]. Moscow, Novoe literaturnoe obozrenie Publ., 2003, pp. 343-486.

2. Gryakalova N. Yu. Chelovek moderna. Biografiya - refleksiya - pismo [The Man of Modernism. Biography - Reflection - Writing]. Saint-Petersburg, Dmitry Bulanin's Publ., 2008. 408 p.

3. Zhirmunskaya T. «Za vsekh rasplachus, za vsekh rasplachus...» ["For All I Will Pay, for All I Will Cry...”]. Kontinent [Continent], 2005, no. 124. Available at: http://magazines.russ.ru/continent/2005/124/zh21.html (accessed 24 November 2011)

4. Ivanov-Razumnik R. V. Vladimir Mayakovsky («Misteriya» ili «Buff») [Vladimir Mayakovsky ("Mystery" or "Bouffe")]. V. V. Mayakovsky: Pro et contra [Vladimir Mayakovsky: Pro et contra]. Saint-Petersburg, The Russian Christian Academy for the Humanities Publ., 2006, pp. 692-728.

5. Kantor K. Trinadtsaty apostol [The Thirteenth Apostle]. Moscow, Progress-Traditsiya Publ., 2008. 368 p.

6. Katsis L. F. Vladimir Mayakovsky: Poet v intellektualnom kontekste epokhi [Vladimir Mayakovsky: the Poet in the Intellectual Context of his Epoch]. Moscow, Russian State University for the Humanities Publ., 2004. 829 p.

7. Krylova N. V. Medny vek: Ocherk teorii i literaturnoy praktiki Russkogo avangarda [The Copper Age: Essay on the Theory and Literary Practice of the Russian Avant-Garde]. Petrozavodsk, 2002. 128 p. 
8. Pyanykh M. Bogoborets s serdtsem Khrista [The Theomachist with the Heart of Christ]. Svobodnaya mysl [The Free Thought], 1993, no. 5, pp. $44-50$.

9. Sillov V. Revolyutsiya dukha (Nietzsche i Mayakovsky) [The Revolution of the Spirit (Nietzsche and Mayakovsky)]. V. V. Mayakovsky: Pro et contra [Vladimir Mayakovsky: Pro et contra]. Saint-Petersburg, The Russian Christian Academy for the Humanities Publ., 2006, pp. 603-606.

10. Tager E. Mayakovsky V. V. [Mayakovsky V. V.]. Bolshaya sovetskaya entsiklopediya [The Great Soviet Encyclopedia]. Moscow, Soviet Encyclopedia Publ., 1938, vol. 38, clmn. 547-555.

11. Tyryshkina E. Kontseptsiya prazdnika v ranney lirike V. Mayakovskogo [The Celebration Concept in the Early Lyrics by Vladimir Mayakovsky]. Alexander Graf (Hg.). Festkultur in der russischen Literatur (18. bis 21. Jahrhundert) (in German) ["The Celebration Culture in Russian Literature of the 18-21th Centuries" by Alexander Graf (Hg.)]. Munich, 2010, pp. 173-182.

12. Ustryalov N. Religiya revolyutsii (Vladimir Mayakovsky) [The Religion of Revolution (Vladimir Mayakovsky)]. V. V. Mayakovsky: Pro et contra [Vladimir Mayakovsky: Pro et contra]. Saint-Petersburg, The Russian Christian Academy for the Humanities Publ., 2006, pp. 499-512.

13. Fatenkov A. N. Sub"ekt v ontologicheskom stolknovenii s Bogom [Person in his Ontological Conflict with the God]. Chelovek [The Human], 2011, no. 1, pp. 107-123.

14. Shalkov D. Yu. Bibleyskie motivy i obrazy v tvorchestve V. V. Mayakovskogo 1912-1918 godov. Dis. ... kand. filol. nauk [The Biblical Motifs and Images in Vladimir Mayakovsky's Literary Works for the 1912-1918s. PhD. philol. sci. diss.]. Stavropol', 2008. 230 p.

15. Shalkov D. Yu. "Obyknovennoe evangelie» «trinadtsatogo apostola»: bibleyskaya simvolika v poeme V. V. Mayakovskogo "Oblako v shtanakh» ["Ordinary Gospel" of the "Thirteenth Apostle": Biblical Symbolism in Vladimir Mayakovsky's Poem "A Cloud in Trousers"]. Russkaya slovesnost', 2008, no. 4, pp. 30-37.

16. Jakobson R. O pokolenii, rastrativshem svoikh poetov [The Generation that Squandered its Poets]. Available at: http://avantgarde.narod.ru/beitraege/ff/ rja_o_pokolenii.htm (accessed 28 November 2011) 